\title{
Acceleration and Timing of Fertile Ovulation in Cyclic Mares with a Deslorelin Implant
}

\author{
By A. Gånheim ${ }^{1}$, A. Gånheim ${ }^{1}$ and W. Jöchle ${ }^{2}$ \\ ${ }^{1}$ Swedish National Stud, Veterinary Services, Flyinge, Sweden, and ${ }^{2}$ Wolfgang Jöchle Assoc., Inc., Denville, NJ, \\ USA.
}

\begin{abstract}
Gånheim A., A. Gånheim and W. Jöchle: Acceleration and timing of fertile ovulation in cyclic mares with a deslorelin implant. Acta vet. scand. 1995, 36, 393-400. - In a blinded trial, the effectiveness and safety of $2.2 \mathrm{mg}$ of the $\mathrm{GnRH}$ analog deslorelin acetate, administered in a short-term implant (STI) to normally cycling mares in estrus with a dominant ovarian follicle of $30 \mathrm{~mm}$ in diameter or larger, were evaluated, using a placebo implant as a negative control. A total of 39 mares received treatments at admittance with pre-randomized implants containing either $2.2 \mathrm{mg}$ or $0 \mathrm{mg}$ deslorelin. Mares were teased daily and examined rectally with ultrasound at $24 \mathrm{~h}$ intervals to determine time to ovulation and duration of estrus. The number of breedings and the pregnancy rate at $18( \pm 3)$ and $38( \pm 3)$ days were recorded, as were systemic side effects and local reactions at the implantation sites. Pregnancies resulting from breedings during the treatment estrus and/or from breedings during the next estrus were followed and the early and late pregnancy loss rate, the number of pregnancies going to term and of live-born foals was recorded.

Mean follicle diameter at treatment was not significantly different between the deslorelin and placebo treatment group with $41.6 \mathrm{~mm}$ and $40.8 \mathrm{~mm}$, respectively.

Treatment with deslorelin STI reduced the time interval to ovulation significantly from $69.5 \pm 25.48 \mathrm{~h}$ to $42.7 \pm 12.35 \mathrm{~h}(\mathrm{p}<0.001)$. The percentage of mares having ovulated within $48 \mathrm{~h}$ rose from $26.3 \%$ to $95.0 \%$, respectively, for placebo and deslorelin STI $(p<0.001)$. As a consequence, the duration of estrus in days and the percent of animals requiring more than 1 breeding were significantly reduced in deslorelin treated animals from 5.4 days to 4.6 days, and from $55.6 \%$ to $5.0 \%$, respectively ( $\mathrm{p}=0.009$ and $=0.001$ ). The percent of mares pregnant from breedings at the treatment estrus $(65.0 \%$ versus $44.4 \%$ ) or the next estrus ( $83.3 \%$ versus $92.3 \%$ ) was satisfactory and similar for deslorelin and placebo treated mares ( $p>0.005$ ), and in $70.0 \%$ and $66.7 \%$ of these once or twice bred mares did pregnancies go to term and live foals were born.
\end{abstract}

\section{GnRH.}

\section{Introduction}

In the mare, length of estrus, interval from onset of estrus to ovulation and size of the follicle at ovulation vary greatly between mares and within mares during the season (Ginther et al. 1972). Consequently, mares have to be bred several times during each estrous period which stresses the stallion's capabilities (Ross- dale \& Ricketts 1980, Ginther 1992). This may result in lower conception rates due to stallion overuse or a delay in breeding of some mares. On the other hand, mares in estrus shipped to the stallion for breeding may show regression of the estrous follicle due to stress and ovulation does not occur. Hence, control of ovulation in the mare has been a goal of the equine 
industry for half a century. The only product known to hasten ovulation reliably with a single treatment is human chorionic gonadotropin (hCG). Single administration will result in ovulation(s) within 24 to $48 \mathrm{~h}$ and in a shortening of the estrous period compared to untreated controls, and thus preserving stallion power (Loy \& Hughes 1966, Ginther et al. 1972, Sullivan et al. 1973, Voss et al. 1975, Shilova et al. 1976, Roser et al. 1980, Rossdale \& Ricketts 1980, Duchamp et al. 1987, Wilson et al. 1990, Harrison et al. 1991, Ginther 1992). Disadvantages of hCG are inconsistencies in response between and within mares and antibody formation which may cause refractoriness (Sullivan et al. 1973, Shilova et al. 1976, Duchamp et al. 1987, Wilson et al. 1990), requiring an increase in dose levels over time. Antibodies may impair fertility or not and can cause anaphylactic reactions (Roser et al. 1980, Wilson et al. 1990). Prostaglandin $\left(\mathrm{PGF}_{2 \alpha}\right)$ and its analogs have been used to accelerate ovulations but not always successfully (Lamond et al. 1975, Duchamp et al. 1987, Squires et al. 1988, Harrison et al. 1991). Their use for this purpose has not been thoroughly researched yet and they are not widely used. GnRH analogs are effective only if given in multiple injections, in $12 \mathrm{~h}$ intervals, 3 to 4 times (average 3.8 times in one study) (Michel \& Rossdale 1986, Squires et al. 1988, Harrison et al. 1991). Hence, a potent GnRH analog, deslorelin acetate, formulated into a short-term release implant (STI $)^{1}$, was evaluated for its suitability to replace hCG. Two doses of 1.3 and $1.8 \mathrm{mg}$ were used and compared directly with the effects 3000 and 5000 I.U. hCG had on the acceleration and timing of ovulations in cyclic mares. Their effects

${ }^{1}$ Ovuplant $^{\mathrm{TM}}$, Peptide Technology Limited, Dee Why, NSW, Australia. were very similar (Meinert et al. 1993). Like hCG, implants must be administered when the lead follicle has attained a critical size $\geq 30$ $\mathrm{mm}$, in large framed breeds like the Hanoverians $\geq 35 \mathrm{~mm}$ ). Ovulations occurred 24 to $48 \mathrm{~h}$ after implantation, with the majority of fertile ovulations 36 to $48 \mathrm{~h}$ after implantation. Endocrinology profiles were established showing sharp elevations of $\mathrm{LH}$ and FSH with peak levels at $12 \mathrm{~h}$, and increased blood concentrations until $48 \mathrm{~h}$ (Meinert et al. 1993). As with hCG, use of these implants without regard to follicular size on days 2 or 3 of estrus yielded unsatisfactory results (Squires 1990).

In 2 dose titration studies with a wide range of doses of deslorelin, the dose of $2.2 \mathrm{mg}$ per implant assured ovulations in $93 \%$ and $94.7 \%$ of all mares within $48 \mathrm{~h}$ after treatment, respectively, and a pregnancy rate of $89.5 \%$ from breedings at the treatment estrus and the next estrus (McKinnon et al. 1993, Squires et al. 1994). The dose of $2.2 \mathrm{mg}$ deslorelin was therefore used in further controlled clinical trials in which the effectiveness of deslorelin STI at this dose was confirmed (Klug et al. 1992, Meyers et al. 1992).

The objective of this blind trial was to evaluate at a Scandinavian stud farm $\left(55.45^{\circ} \mathrm{N}\right.$ and $13.21^{\circ} \mathrm{E}$ ) the efficacy of the $2.2 \mathrm{mg}$ dose of deslorelin, administered in a biocompatible implant, to advance (accelerate) ovulation in cyclic mares and assure its timing. i.e. to occur 24 to $48 \mathrm{~h}$ after implantation, versus a placebo implant. In addition, the effect of deslorelin treatment versus a placebo implant was evaluated on early pregnancy rate, on pregnancies going to term and to produce a healthy foal; systemic side effects and local reactions at the implantation sites were recorded.

\section{Materials and methods}

Experimental animals

During the 1992 breeding season, a total of 39 
light riding type horse mares were treated at random with either deslorelin STI $(n=20)$ or placebo $(n=19)$, consisting of Standardbred Trotters (13.9\%), Thoroughbreds (5.6\%), Swedish Warmbloods (33.3\%) and Halfbloods $(47.2 \%)$. Mares ranged in age from 3 to 20 years, with a mean of 9.14 years. Of the total of 39 mares, 18 were lactating, 9 were barren, 8 mares were maiden and 4 mares had not been bred in 1991 .

Mares coming to the stud from different locations had previously been subjected to a variety of feeding regimens, vaccinations and deworming procedures. All resulted in the admission of sound mares with an average body condition score of 5.51 (range: 4 to 6; moderate to fleshy) (Henneke et al. 1983). Mares were subjected to identical management and feeding conditions at the location.

\section{Material}

Number coded implants (20 deslorelin and 20 placebo implants) were provided by the sponsor. They had been randomized in advance, with each implant contained in a vial showing a number from 1 to 40 . Deslorelin STI and placebo implants were equal in size $(2.3 \mathrm{~mm}$ diameter $\times 3.7 \mathrm{~mm}$ length) and white color and contained $2.2 \mathrm{mg}$ an $0.0 \mathrm{mg}$ deslorelin, respectively.

\section{Methods}

The trial was conducted as a blinded study, with the persons inserting the implants and assessing response to treatment being completely unaware of the treatment each mare had received. The code to the treatments was available to the sponsor's agent (WJ) and the biostatistician only.

The number of the prepackaged implants corresponded with the number each mare received at admission, when mares were numbered consecutively.
Cycling mares were teased daily for signs of estrus. Their reproductive tract was examined per rectal examination and with ultrasonography every 2 to 3 days until the mares showed clinical and behavioral signs of estrus. The day estrus symptoms / behavior were first observed was called day 1 . From Day 1 on, ovaries were examined per rectum and with ultrasonography in $24 \mathrm{~h}$ intervals. After implantation, ovaries were examined per rectum and with ultrasound in $24 \mathrm{~h}$ intervals until ovulation occurred. Growth of all follicles $\geq 20 \mathrm{~mm}$ was recorded. Mares in estrus with a follicle which had reached $\geq 30 \mathrm{~mm}$ were admitted to the study and were assigned automatically by the above mentioned procedure to 1 of 2 treatment groups. Accordingly, each group contained mares in similar reproductive status and range of follicular sizes.

After allocation to their treatment group, mares were implanted immediately with the designated implant. An 11-gauge needle wide enough to accommodate the implant was used. After penetrating the skin on the left of the neck, the implant was deposited subcutaneously using an obturator. Before implantation, the skin at the implantation site at the mare's neck was disinfected.

\section{Treatment evaluation measures}

As described above, ovarian activity and the occurrence of ovulation were evaluated after deslorelin implantation in $24 \mathrm{~h}$ intervals until ovulation had been confirmed. The time interval between treatment and the time at which ovulation had been confirmed was recorded, as was the duration of estrus (in days). Mares with a preovulatory follicle were inseminated with fresh, cooled or frozen semen every other day, or immediately in case ovulation had occurred between the 2 last examinations. The number and dates of each breeding were recorded. Pregnancy diagnosis was 
Table 1. Time to ovulation (hours) following treatment with deslorelin STI ${ }^{1}$ or with a placebo implant.

\begin{tabular}{lcc}
\hline & \multicolumn{2}{c}{ Treatment Group } \\
\cline { 2 - 3 } & Deslorelin & Placebo \\
\hline Mean & $42.7^{\mathrm{a}}$ & $69.5^{\mathrm{b}}$ \\
Standard Deviation & 12.4 & 25.5 \\
Number of Mares & 20 & 19 \\
Percent ovulating & & \\
within 48 hours & $95.0^{\mathrm{a}}$ & $26.3^{\mathrm{b}}$ \\
\hline
\end{tabular}

a, b Group means with differing superscripts are significantly different at $\mathrm{p}<0.001$.

${ }^{1} \mathrm{STI}=$ Short-term release implant.

made by ultrasonography 18 (13-20) and 38 (35-50) days after breeding, and presence or absence of embryos or fetuses, singles or twins, recorded. Mares were removed from the clinical phase of the study when they were confirmed pregnant, or on day 40 after treatment when they had not conceived from breedings after treatment or at the next regular estrus.

Mares were observed for general and local side effects after treatments. Observations were made daily for the first 6 days after implantation and once weekly thereafter, for a total of 3 weeks. The following criteria were used for assessing reactions at the implantation site: (1) visible signs of swelling; (2) sensitivity to touch, and (3) skin temperature over implantation site, using scores ranging from unchanged $(=0)$ to significant $(=3)$.

\section{Statistical evaluation}

Data on quantitative variables (e.g. the time to ovulation) were statistically evaluated via one-way analysis of variance with treatment (i.e., deslorelin implantation or placebo implantation) as the main effect. Data on qualitative variables, e.g. number of breedings (inseminations) during the treatment estrus and the next estrus and pregnancy rates resulting from these breedings, were evaluated via
Table 2. The number of observed days of estrus of mares treated with deslorelin STI $^{1}$ or a placebo implant.

\begin{tabular}{lcc}
\hline & \multicolumn{2}{c}{ Treatment Group } \\
\cline { 2 - 3 } & Deslorelin & Placebo \\
\hline Mean & $4.55^{\mathrm{a}}$ & $5.7^{\mathrm{b}}$ \\
Standard Deviation & 0.83 & 1.01 \\
Number of Mares & 20 & 19 \\
\hline
\end{tabular}

a, b Group means with different superscripts are significantly different, $(\mathrm{p}<0.001)$.

${ }^{1} \mathrm{STI}=$ Short-term release implant.

standard Chi-square tests for contingency tables. The data on the incidence of adverse clinical signs at the implantation site were also evaluated via Fisher's Exact Test because of the extremely low incidence in this study (Cochran \& Cox 1975).

\section{Results}

Clinical observations made regarding time to ovulation after treatment in hours, the percentage of ovulations within $48 \mathrm{~h}$, the duration of estrus, the number of breedings, and if the mare became pregnant or not from breedings during the treatment estrus and / or during estrus periods, are shown in Tables $1-3$. Mean follicle diameter at treatment of $41.6 \mathrm{~mm}$ and $40.8 \mathrm{~mm}$ for the deslorelin and placebo group, respectively, did not differ statistically significantly.

The time interval between treatments and ovulations in hours was significantly different $(\mathrm{p}<0.001)$ between deslorelin STI and placebo implant, with $42.7 \mathrm{~h}$ versus $69.5 \mathrm{~h}$, respectively (Table 1). The percentage of mares ovulating within $48 \mathrm{~h}$ was significantly different $(\mathrm{p}<0.001)$ between deslorelin STI and placebo treated mares (Table 1), with $95.0 \%$ versus $26.32 \%$, respectively.

Duration of estrus in deslorelin STI treated mares was significantly shorter $(p=0.009)$ as 
Table 3. Percent ${ }^{1}$ of mares requiring more than 1 insemination, percent of mares pregnant at the 18 th day of each of the treatments and the next estrus cycles following treatments and foaling rates by treatment group.

\begin{tabular}{llll}
\hline & \multicolumn{2}{c}{ Treatment Group } & \\
\cline { 2 - 3 } Percent of Mares & Deslorelin & Placebo $^{3}$ & \\
\hline Requiring more than & 5.0 & 55.6 & 0.001 \\
one insemination & $1 / 20$ & $10 / 18$ &
\end{tabular}

Pregnant at the 18th

day of:

Treatment estrus

$\begin{array}{lll}65.0 & 44.4 & 0.204 \\ 13 / 20 & 8 / 18 & \end{array}$

Next estrus ${ }^{4}$

$\begin{array}{ll}83.3 & 92.3 \\ 15 / 18 & 12 / 13\end{array}$

0.462

Foaling rate from

breeding at the

Treatment estrus

$\begin{array}{lcc}50.0 & 44.0 & \text { n.s. } \\ 10 / 20 & 8 / 18 & \end{array}$

$\begin{array}{llll}\text { Next estrus } & 70.0 & 66.7 & \text { n.s. }\end{array}$

$14 / 20 \quad 12 / 18 \quad$ n.s.

$\begin{array}{llll}\text { At any estrus later } & 75.0 & 77.8 \quad \text { n.s. }\end{array}$ in the season $\quad 15 / 20 \quad 14 / 20$

1 The denominator of each percent was the number of treated mares with data available, as shown.

2 n.s. = non significant.

3 Only 18 out of 19 mares were bred in this group.

4 Lower numbers reflect the mares not bred at the next estrus: 2 and 5 in the deslorelin and placebo group, respectively.

compared with placebo treated mares from 5.37 days to 4.55 days (Table 2). As a consequence, the mean number of breedings during the treatment estrus was reduced by $31 \%$ from 1.53 to 1.05 , respectively. In the placebo group, $55.6 \%$ of the mares were bred twice, compared to only $5.0 \%$ of the mares treated with deslorelin ( $\mathrm{p}=0.001)$ (Table 3$)$.

Pregnancy rates on days 18 and 38 ensuing from breedings at the treatment estrus and/or the next estrus were not different between treatment groups (Table 3 ). There were no effects of treatment on pregnancy rates $(55.3 \%$ and $66.7 \%$ overall) from inseminations at the first and second estrus. The overall pregnancy rate of $76.37 \%$ from both breedings for both treatment groups combined was highly satisfactory. Two of the pregnancies from breeding at the treatment estrus were lost early, both from the deslorelin group and 1 deslorelin treated mare aborted later. All pregnancies were followed to term. Their percentage and that of liveborn foals are shown in Table 3. As a result of breeding during the treatment estrus and the next estrus, $70.0 \%$ of the deslorelin treated mares, and $66.7 \%$ of the placebo treated mares, gave birth. Over the entire season, the foaling rate for both groups was $75.0 \%$ and $77.8 \%$, respectively.

\section{Side effects}

No systemic side effects to treatments were seen. Clinical observations regarding the implantation site are shown in Table 4. The overall incidence for observed swellings, sensitivity to touch and elevated skin temperature was $18.0 \%, 15.4 \%$ and $5.1 \%$, respectively.

Of importance was the observation that mean ratings for swellings, sensitivity to touch and the rare impression of elevated local temperature, were only "slight" (score 1) and in all cases did not last longer than 2 days, with no significant differences between deslorelin or placebo implants (Table 4). There was no need for local or systemic treatments in response to a local reaction at the implantation site.

\section{Discussion}

Treatments with $2.2 \mathrm{mg}$ deslorelin STI accelerated ovulations as previously reported (Squires 1990, Klug et al. 1992, Meyers et al. 1992, Meinert et. al. 1993, McKinnon et al. 
Table 4. Incidence ${ }^{1}$ of visible swelling, sensitivity to touch, and elevated skin temperature at the implantation site of mares following treatment with deslorelin $\mathrm{STI}^{2}$ or a placebo implant.

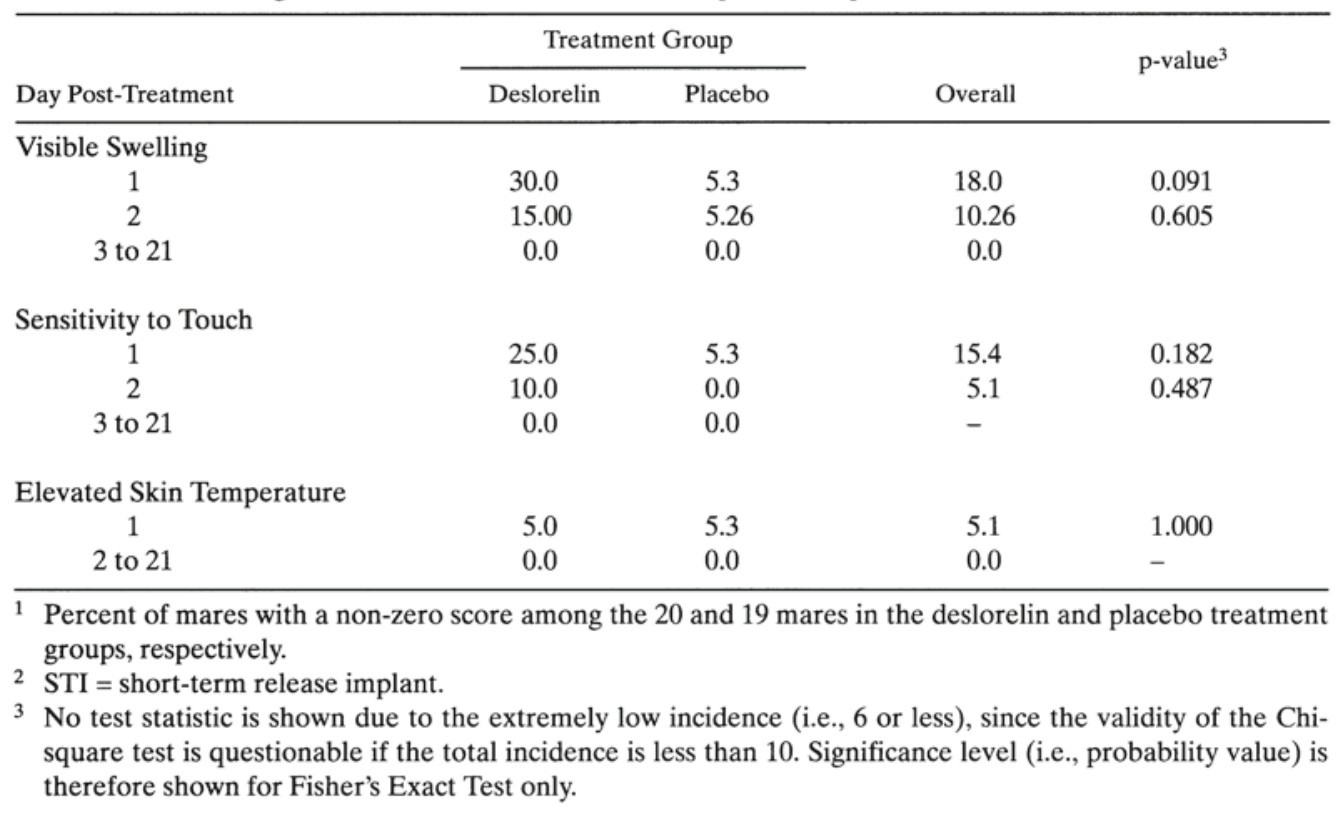

1993, Squires et al. 1994). This effect was evident also from the high percentage of mares overall that ovulated within $48 \mathrm{~h}$ after treatment. In general, the dose of $2.2 \mathrm{mg}$ deslorelin administered as a short-term implant accelerated ovualtions and resulted in shortened heat periods and a markedly reduced number of breedings required during the treatment estrus, without altering fertility. This was reflected in similar and very satisfying pregnancy rates. These rates are very similar to those reported elsewhere (for a comprehensive review, see Ginther 1992). Of special interest was the observation that a subgroup of mares which were inseminated only once during the treatment estrus with frozen semen (10 mares treated with deslorelin STI and 8 mares with placebo implant) showed a difference between treatments in a pregnancy rate of $7 / 10$ and $1 / 8$, respectively.
The clinical results on drug effectiveness from this study are similar to those reported by others, and confirmed that the tested product elicited very similar responses independently of breed, geographic location and climate (Squires 1990, Klug et al. 1992, Meyers et al. 1992, Meinert et. al. 1993, McKinnon et al. 1993, Squires et al. 1994). The difference in pregnancy rates for mares inseminated with frozen semen indicates that pinpointing ovulation with deslorelin STI may enhance fertility if semen of limited life span or low motility is used close to the anticipated time of ovulation. The striking reduction in mares inseminated more than once (Table 3) confirms that correct use of deslorelin STI provides for significant savings of sperm portions and with it a sparing of stallion power. At the performance level experienced in this study, deslorelin STI replaces hCG effectively and safely; 
overall fertility after deslorelin STI treatment, as measured by early pregnancy rates and pregnancies going to term successfully and producing healthy offspring, was unimpaired. No systemic side effects were observed in response to the implantation of either $2.2 \mathrm{mg}$ deslorelin STI or placebo implants. Local reactions at the implantation sites (Table 4) were only slight and short lived; they had disappeared after $72 \mathrm{~h}$ and did not require systemic or local treatment. These reactions were similar to those observed in all previous studies. The impression that deslorelin STI caused a slightly higher level of recordings (Table 4) was not statistically significant.

\section{Conclusion}

Treatment of mares in estrus with a dominant ovarian follicle of $30 \mathrm{~mm}$ or larger with an implant containing $2.2 \mathrm{mg}$ of the $\mathrm{GnRH}$ analog deslorelin reliably resulted in an acceleration of ovulation(s) occurring within $48 \mathrm{~h}$ in most animals. As a consequence, duration of estrus, and the number of breedings was often reduced without jeopardizing fertility. In this controlled study, early pregnancy rates were similar for deslorelin STI and placebo treated mares, whether conceiving at the treatment estrus or the next estrus, and foaling rates were equal.

\section{Acknowledgments}

Dr. T. J. Keefe, EnviroStat, Fort Collins, CO, USA, provided implant randomization and statistical evaluation of the clinical data. Mr. B. Svenson, BI-vet, Malmö, Sweden, assisted with the study permit and with drug importation. The study was sponsored by Peptide Technology, Ltd., Dee Why, NSW, Australia (Dr. T. E. Trigg).

\section{References}

Cochran WG, Cox GM: Experimental Designs (2nd ed). John Wiley \& Son, Inc., New York, NY, USA, 1975.
Duchamp G, Bour B, Combarnous Y, Palmer E: Alternative solutions to hCG induction of ovulation in the mare. J. Reprod. Fert., Suppl. 1987, $35,221-228$.

Ginther OJ, Whitmore HL, Squires E.L: Characteristics of estrus, diestrus and ovulation in mares and effects of season and nursing. Amer. J. Vet. Res. 1972, 33, 1935-1939.

Ginther OJ: Reproductive biology of the mare. Basic and applied aspects. Equiservices, Cross Plains, WI, 1992.

Harrison LA, Squires EL, McKinnon AO: Comparison of HCG, buserelin and luprositol for induction of ovulation in cycling mares. J. Equine vet. Sci. 1991, 11, 163-166.

Henneke RD, Potter GD, Kreider JL, Yeates, DF: Relationship between condition score, physical measurements and body fat percentage in mares. Equine vet. J. 1983, 15, 371-372.

Klug E, Meinert K, v. Lepel J, Erbslöh J, Biet K, Lübekke M, Bader H, Merkt H, Jöchle W: Acceleration of ovulation in the mare with a short-acting subcutaneous implant of the GnRH analog deslorelin. Proc. Internat. Congr. Anim. Reprod., The Hague; 1992, 4, 1879-1881.

Lamond DR, Buell JR, Stevenson, WS: (1975) Efficacy of a prostaglandin analogue in reproduction in the anoestrous mare. Theriogenology 1975, 3, $77-85$.

Loy RG, Hughes, J.P: The effects of human chorionic gonadotropin on ovulation, length of estrus, and fertility in the mare. Cornell Vet. 1966, $56,44-50$.

McKinnon AO, Nobelius AM, Tarrida del Marmol Figueroa S, Skidmore J, Vasey JR, Trigg, TE: Predictable ovulation in mares treated with an implant of the GnRH analogue deslorelin. Equine Vet. J. 1993, 25, 321-323.

Meinert C, Silva JFS, Kroetz I, Klug E, Trigg TE, Hoppen $\mathrm{HO}$, Jöchle, W: Advancing the time of ovulation in the mare with a short-term implant releasing the $\mathrm{GnRH}$ analogue deslorelin. Equine Vet. J. 1993, 25, 65-68.

Meyers PJ, Jöchle W, Samper JC, Sealey L, Conboy $H S$, Squires E, Reid MP, Bowman RT, Taylor BC, Gimenez T, Schlager R.L, Dimmick, M.A: Efficacy of the GnRH analog, deslorelin, given as a short-acting subcutaneous implant, in accelerating ovulation in the mare. Proc. Internat. Congr. Anim. Reprod., The Hague; 1992, 4, 1897-1899.

Michel TH, Rossdale, PD: Efficacy of human chorionic gonadotrophin and gonadotrophin releas- 
ing hormone for hastening ovulation in Thoroughbred mares. Equine vet. J. 1986, 18, 438-442.

Roser JF, Evans JW, Kiefer BL, Neely DP, Pacheco, $C A$ : Reproductive efficiency in mares with antihCG antibodies. Proc. 9th Int. Congr. Anim. Reprod. and A.I., Madrid, Spain, 1980, 4, 627-630.

Rossdale PD, Ricketts, SW: Equine stud farm medicine. Lea \& Febiger, Philadelphia, 1980.

Shilova AV, Platov EM, Lebedev ST: The use of human chorionic gonadotropin for ovulation date regulations in mares. Proc. VIII Int. Congr. Anim. Reprod. and AI (Krakow) 1976, 3, 204207.

Squires E: personal communication; report on file. 1990.

Squires EL, Harrison LA, McKinnon A.O, Voss JL: Use of hCG, GNRH agonist or prostaglandin analogue for induction of ovulation in mares. 11th Internat. Congr. Animal Reprod. \& A.I., Dublin, 1988, p.460.

Squires EL, Moran DM, Farlin ME, Jasko DJ, Keefe TJ, Meyers SA, Figueiredo E, McCue PM, Jöchle, W: Effect of dose of GnRH analog on ovulation in mares. Theriogenology, 1994, 41, 757-769.

Sullivan JJ, Parker W.G, Larson LL: Duration of estrus and ovulation time in non-lactating mares given human chorionic gonadotropin following its repeated injection in the cyclic mare. J. Reprod. Fert. Suppl. 1973, 27, 173-179.

Voss JL, Sullivan JJ, Pickett BW, Parker WG, Burwash $L D$, Larson, L.L: The effect of hCG on duration of oestrus, ovulation time and fertility in mares. J. Reprod. Fert., Suppl. 1975, 23, 297-301.

Wilson CG, Downie CR, Hughes JP, Roser JF: Effects of repeated hCG injections on reproductive efficiency in mares. Equine Vet. Sci. 1990, 10, 301-308.

\author{
Sammanfattning \\ Påskyndande och förutsägande av ovulation hos sto \\ med hjälp av ett deslorelinimplantat.
}

En potent GnRH analog, deslorelinacetat, i form av ett implantat med korttidsfrisättning har provats i olika koncentrationer för att utvärdera möjligheten att ersätta HCG. Dosen $2.2 \mathrm{mg}$ deslorelin per implantat befanns optimal. I ett kliniskt försök under 1992 behandlades 20 ston med deslorelin och 19 ston med placeboimplantat. Stona kontrollerades dagligen på förekommande brunsttecken och undersöktes rektalt och med ultraljud var 24 timme. Ston med folliklar $\geq 30 \mathrm{~mm}$ togs in i försöket. Implantatet sattes in subcutant på halsens vänstra sida med en 3 mm kanyl. Stona seminerades med färsk, kyld eller fryst sperma. Dräktighetsdiagnos ställdes via ultraljud på dag 18 och 38 . Tidsintervallet mellan behandling och ovulation skilde signifikant mellan grupperna med 42,7 tim och respektive 69,2 tim för deslorelinbehandlade ston resp placebobehandlade. $95 \%$ behandlade ston ovulerade inom 48 tim mot $26,32 \%$ av de obehandlade. Brunstens längd förkortades signifikant $(4,55$ dagar mot 5,37$)$ och därmed antalet semineringar / betäckningstillfällen. Ingen skillnad i dräktighetsprocent samt fölningsprocent förelåg. Inga eller mycket lindriga bieffekter $i$ form av svullnad på halsen efter implantatet noterades.

(Received May 24, 1994; accepted May 24, 1995).

Reprints may be obtained from: A. Gånheim, National Stud, Veterinary Services, S-24032 Flyinge, Sweden. 